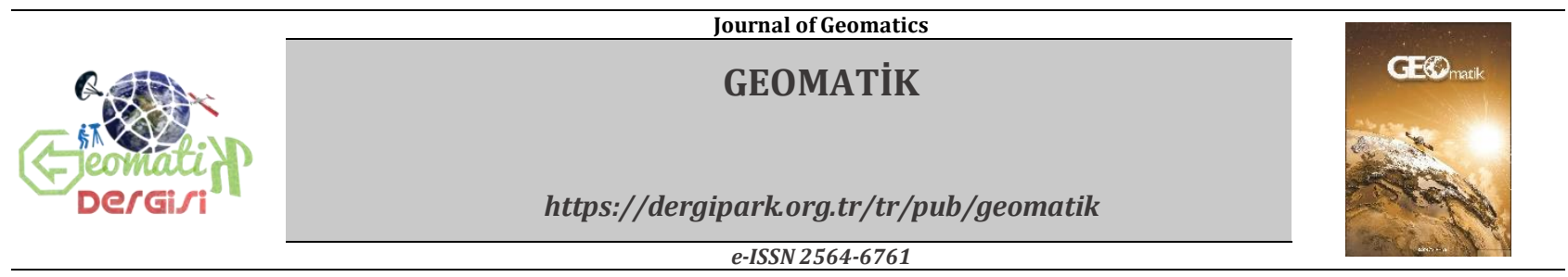

\title{
İnsansız hava aracından elde edilen veriler ile kaya düşme potansiyelinin değerlendirilmesi: Adam Kayalar örneği, Mersin
}

\author{
Müge Ağca*1, Nurgül Yeşiloğlu Gültekin², Efdal Kaya³ \\ 1İzmir Kâtip Çelebi Üniversitesi, Mühendislik ve Mimarlık Fakültesi, Harita Mühendisliği Bölümü, İzmir, Türkiye \\ ¿Ulaştırma ve Altyapı Bakanlığı, Altyapı Yatırımları Genel Müdürlüğü, Araştırma Dairesi Başkanlığı, Ankara, Türkiye \\ 3İskenderun Teknik Üniversitesi, Mimarlık ve Şehir Planlama Bölümü, İskenderun, Türkiye
}

\author{
Anahtar Kelimeler \\ SYM \\ İnsansız Hava Aracı (İHA) \\ Kaya Düşmesi \\ 3 Boyutlu Modelleme \\ HY-STONE
}

\begin{abstract}
ÖZ
Tarihi ve kültürel miras alanlar, bazen doğa șartları bazen de insan müdahalesi ve iklimsel faktörlerin etkisiyle hızla değișime ve deformasyona uğrayan alanlardır. Bu tür alanları korunmak için ileri teknolojilerden ve bilimsel çalışmalardan faydalanmak gerekmektedir. $\mathrm{Bu}$ amaçla kaya düşmelerinin yoğun olarak görüldüğü Mersin'de bulunan Adam Kayaları ve yakın çevresi çalışma alanı olarak seçilmiştir. Bu çalışmanın genel amacı, İnsansız Hava Aracı (IHA) sisteminden elde edilen yüksek kalitedeki topografik veriler kullanılarak bölgede olabilecek kaya düşmelerinin 3B modelinin oluşturulması ve değerlendirilmesidir. Çalışma kapsamında, İHA sisteminin kaya düşmesi çalıșmalarında kullanılabilirliği araştırılmıștır. Arazi çalıșmaları kapsamında bulunan jeolojik malzemelerin tanımlaması yapılmış ve modelleme aşamasında kullanılmak üzere çalışma alanından alınan blok örneklerinin fiziksel, indeks ve mekanik parametreleri belirlenmiștir. Çalışmada, İHA sisteminden elde edilen yüksek doğruluktaki verilerle olușturulan Sayısal Yükseklik Modeli (SYM) kaya düșmelerinin 3B modellemesine imkân sağlayan ve değerlendirilmesinde kullanılan HY-STONE yazılımında girdi olarak kullanılmıştır. Sonuç olarak, İHA sistemi kullanılarak Adam Kayaları civarındaki kaya düşmesi kaynak alanları değerlendirilmiş ve bölgedeki kaya düşme potansiyeli olan blokların modellemesi başarılı bir șekilde gerçekleștirilmiştir. Çalışmanın çıktıları, kültürel mirasların korunması ve bu tür turistik alanlarda kaya düşmelerinden kaynaklanabilecek can ve mal kayıplarının önlenmesi açısından büyük önem tașımaktadır.
\end{abstract}

\section{Evaluation of rock fall potential using data from unmanned aerial vehicles: A case of Adam Kayalar, Mersin}

Keywords
DEM
Unmanned Aerial Vehicle
(UAV)
Rock Fall
3D Modelling
HY-STONE

\begin{abstract}
Historical and cultural heritage sites are areas that undergo rapid change and deformation due to natural conditions and sometimes human intervention and climatic factors. It is necessary to benefit from advanced technologies and scientific studies to protect such areas. Scientific studies can help to protect these areas. For this purpose, Adam Kayalar and its surroundings located in Mersin was selected as our study area where rock falls is very intense. The overall aim of this study is to construct 3D model and evaluate the potential of rockfall in the study area by using high quality topographic data obtained from Unmanned Aerial Vehicles (UAV). In this study, the usability of the UAV system in rockfall studies was investigated. The geological materials within the scope of the field studies were defined and the physical, index and mechanical parameters of the block samples taken from the study area were determined for the modeling stage. The high accuracy data obtained from the UAV system was used as an input in the 3D rockfall modeling software, HY-STONE, to be used for the evaluation of rockfalls. As a result, rockfall source areas around Adam Kayalar were evaluated and modeling of blocks with rockfall potential in the region was successfully performed by using UAV data. The outputs of the study are of great importance for the protection of cultural heritage and prevention of loss of life and property that may result from rock falls in such tourist areas.
\end{abstract}

*(mugekaan@gmail.com) ORCID ID 0000-0003-0190-7280 (nurgulyesiloglu@yahoo.com) ORCID ID 0000-0002-7007-2478 (efdal.kaya@iste.edu.tr) ORCID ID 0000-0002-5553-0143
AĞCA, M , GÜLTEKIN, N , KAYA, E . (2020). İnsansız Hava Aracından Elde Edilen Veriler ile Kaya Düșme Potansiyelinin Değerlendirilmesi: Adam Kayalar Örneği, Mersin. Geomatik, 5 (2) , 134-145. DOI: 10.29128/geomatik.595574 Retrieved from https://dergipark.org.tr/tr/pub/geomatik/issue/52495/595574 


\section{GíRiş}

Kültürel, doğal ve tarihi miraslar bir milletin geçmişi ile geleceği arasındaki en önemli köprülerden biridir. Tarihi ve kültürel miras alanları, bazen doğa şartları bazen de beşeri faktörlerin etkisiyle hızla değişime ve deformasyona uğrayan alanlardır. $\mathrm{Bu}$ tür yerlerin arşivlerinin oluşturulmasında, restorasyon ve röleve çalışmalarında, sayısal olarak görüntülenmelerinde, üç boyutlu (3B) taranması ve modellemesinde, hukuki, teknik ve doku bilgilerinin oluşturulmasında uzaktan alglama ve fotogrametrik yöntemler önemli rol oynamaktadır. Tarihi ve kültürel alanların 3B modelleme çalışmalarında, deformasyona uğrayan alanların tespitinde, heyelan analizlerinde aktif uzaktan algllama sistemlerinden olan yersel lazer tarama cihazları gün geçtikçe artan bir şekilde kullanılmaktadır. Fakat yersel lazer tarama sistemlerinin arazinin topografik yapısından dolayı yetersiz kalabildiği durumlar olabilmekte ve istenilen ölçümler ve analizler gerçekleştirilememektedir.

Son zamanlarda, yeni bir taşıyıcı platformu olan İHA, fotogrametri ve uzaktan algilama yoluyla coğrafi veri üretiminde kendisine birçok kullanım alanı bulmuştur. Geliştirilen İHA sistemlerine fotogrametrik ölçümler yapabilen sistemler ve kameralar entegre edilebilmektedir. Veri elde edilmek istenen alanın üzerinden İHA ile uçularak bölgenin hava fotoğrafları çekilebilmekte ve bu fotoğraflardan bölge ile ilgili detaylı yüzey ve yükseklik modeli bilgileri elde edilebilmektedir. Bu araçlar, hızlı, hassas, düşük maliyetli ve tekrarlı ölçü elde etme özelliklerinden dolayı birçok yerel ölçüm çalışmalarında kullanılmaya başlanmıștır. Genel olarak, İHA sistemleri ile arazinin $2 \mathrm{~B}$ ve $3 \mathrm{~B}$ topografik verilerini elde etmek mümkündür. Kaya düşmelerinin değerlendirilmesine ve $3 \mathrm{~B}$ modellenmesine yönelik literatürde birçok çalışma bulunmaktadır. Literatürde, yapılan analizler ve modellemeler için gerekli olan girdiler optik veriler (Deliormanlı vd., 2014), yersel lazer tarama (Salvini vd., 2013; Uysal ve Uslu, 2017; Kromer vd., 2015; Salvini vd., 2013; Gonçalves vd., 2015) ve havadan Lidar tarama sistemlerinden (Lan vd. 2010; Lai vd., 2014; Thoeni vd., 2014; Lato vd., 2014; Vasuki vd., 2014) elde edilmiștir. Yapılan bazı çalışmalarda bu sistemlerin bir arada (Kasprak vd., 2019; Bonneau ve Hutchinson, 2019; Guisado-Pintado vd., 2019; Wenzhong vd., 2018; Solazzo vd., 2018; Walton vd., 2018) yada sadece yakın resim fotogrametrisi kullanıldığı da görülmektedir (Şanlıoglu vd., 2013; Yakar vd., 2009).

Çalışmada nümerik kaya düşmesi analiz programı olan HY-STONE (Agliardi vd., 2009) kullanılmıştır. HY-STONE Guzzetti vd. (2002) tarafindan geliştirilen HY-STONE yazılımının son şeklidir. Bu çalışma kapsamında gerçekleştirilen üç boyutlu nümerik kaya düşme analizleri kaya düşmesi kaynak alanından başlayan kaya bloğunun düşme, sıçrama, yuvarlanma vb. hareketlerini, kaya bloğu duruncaya kadar izlediği yolu, enerji değişimlerini ve hızını içermektedir. Guzzetti vd. (2002) çalışmalarında kaya düşme tehlikesinin değerlendirilmesi için 3 boyutlu HY-STONE yazılımını geliştirmişledir. $\mathrm{Bu}$ yazılımla kaya düşmelerinin modellenmesinin diğer programlarla karşılaştırıldığında daha gerçekçi sonuçlar verdiği ifade edilmiştir. Agliardi vd. (2009) Varenna/İtalya'da meydana gelen kaya düşmeleri için risk değerlendirmesi yaptıkları çalışmalarında üç boyutlu modelleme programı olan HY-STONE'u kullanmışlardır. $\mathrm{Bu}$ çalışmanın literatürdeki çalışmalardan farkı, kaya düşmelerinin değerlendirilmesine yönelik Sayısal Yükseklik Modeli (SYM), eğim haritası, ortofoto gibi topografik verilerin İHA'dan elde edilmesidir.

Adam Kayaları dünyada benzeri az bulunan ve ülkemiz için önemli tarihi ve kültürel değere sahip olup, birçok yerli ve yabancı turist tarafindan ziyaret edilmektedir. Adam Kayaları'nın dik bir yamaçta yer almasından dolayı, söz konusu alana gelen ziyaretçiler bu civardaki kaya düşmeleri nedeniyle can ve mal kaybına uğrayabileceklerdir. Bu çalışma bölgede olabilecek kaya düşmelerinden korunmak ve kaya düşmelerinden kaynaklanabilecek can ve mal kayıplarını önleme açısından büyük önem taşımaktadır. Bu çalışma ile kaya düşmelerinden sadece ziyaretçilerin değil, aynı zamanda kabartmaların da korunması söz konusu olacaktır. Ayrıca bu çalışma ile İHA sisteminden elde edilen verilerin bu tür çalışmalarda kullanılabilirliği tartışılmıştır.

\section{2. ÇALIŞMA ALANI}

Çalışma alanı olarak Mersin'in önemli turizm merkezlerinden Erdemli'ye bağlı Kızkalesi Mahallesi'ne yaklaşık 7 kilometre mesafede Şeytan Deresi Vadisi'nde bulunan Adam Kayaları bölgesi seçilmiştir. Çalıșma alanının yer bulduru haritası Şekil 1'de yer almaktadır. Şekil 2 Adam Kayaları'nın genel görünümünü vermektedir. Arkeolojik açıldan da büyük önem taşıyan bu alan, Erdemli ilçesinde Şeytan Deresi Vadisi'nin sarp yamaçlarına M.Ö. 1. yüzyıl ile M.S. 2. Yüzyıl arasında yapıldığı tahmin edilen büyük boyutta insan kabartmalarına sahiptir. Kabartmaların tamamının yapımı 250 yılda gerçekleşmiş olmakla birlikte, kabartmaların stil özellikleri bu süreci yansıtmaktadır. Kabartmaların sarp bir yamaç üzerinde bulunduğu ve bu alanda meydana gelmiş kaya düşmeleri bilindiği dikkate alındığında Adam Kayaları alanında ziyaretçilerin zarar görme olasılığının oldukça yüksek olduğu aşikârdır. 


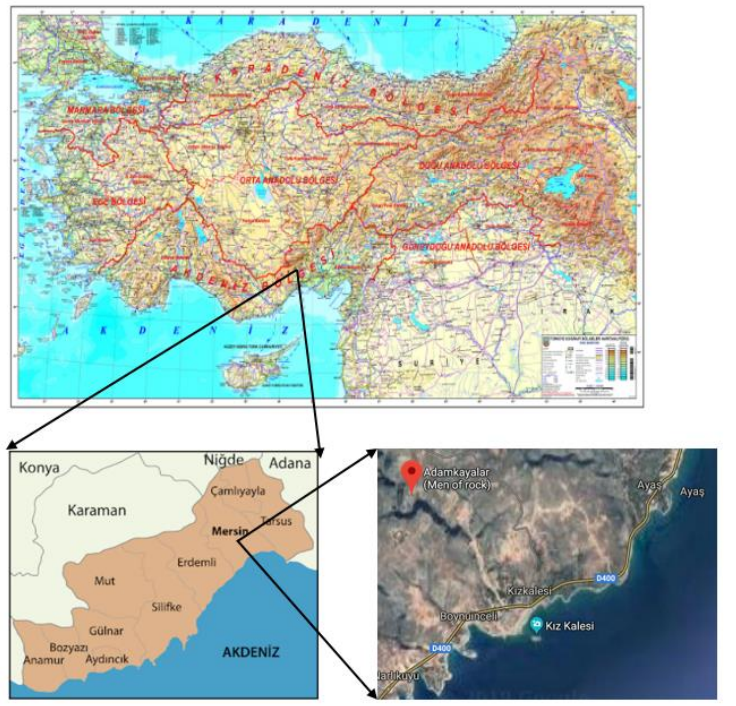

Şekil 1. Çalışma alanı yer bulduru haritası (Google Earth, 2018).
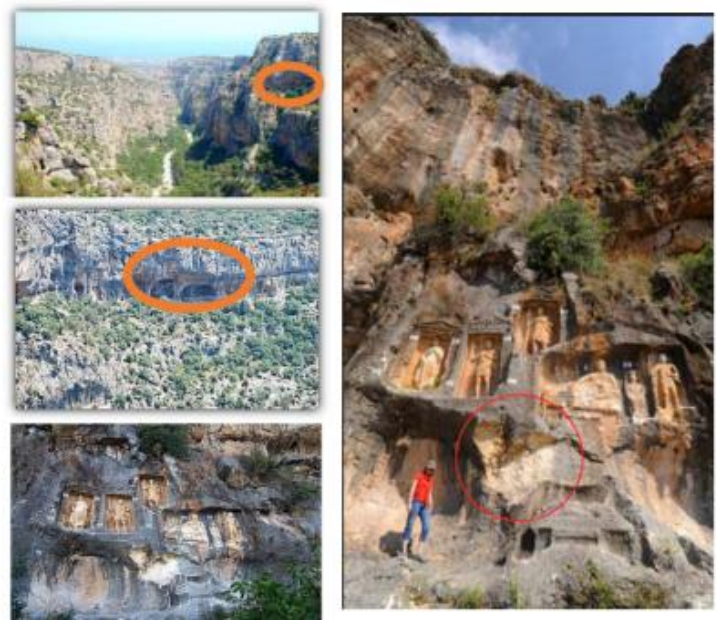

Şekil 2. Adam Kayaları'nın genel görünümü (URL-1).

\section{YÖNTEM}

Çalışmanın amacına ulaşmak için arazi çalışması, laboratuvar analizleri ve arazinin 3B kaya düşme potansiyeli modellenmiş ve sonuçlar değerlendirilmiştir.

\subsection{Arazi Çalışması ve Laboratuvar Analizleri}

Bu çalışmada arazi çalışmaları kapsamı altında "Fotogrametrik Analizler" ve "Jeolojik Analizler" gerçekleştirilmiștir.

\subsubsection{Fotogrametrik analizler}

Arazinin 3B modellenmesinde ve kaya düșme analizinde kullanılan SYM IHA'dan elde edilmiștir. İHA sistemleri düşük maliyet ile yüksek performansa sahip olmasından dolayı günümüzde birçok disiplin tarafından kullanılmaktadır. Bu sistemler ile oldukça alçak uçuşta yüksek hassasiyette elde edilen görüntüler geleneksel hava fotogrametrisinden elde edilen görüntülere göre daha düşük maliyettedir (Esposito vd., 2014).
Bu çalışmada, Parrot Group tarafından üretilen SenseFly eBee Rtk model uçak kullanılmıștır. Bu uçağa ait teknik özellikler Tablo 1'de verilmiștir. İHA ile uçuş yapılan alan yaklaşık 102 hektardır. Çalışmada yer örnekleme alanı (YÖA) $5.9 \mathrm{~cm}$ olarak belirlenmiştir. Çalışmada 10.6 mm odak uzaklığı olan SODA markalı kamera kullanılmıștır. Elde edilecek görüntülerin, enine ve boyuna bindirme oranı $\% 85$ olarak ayarlanmıştır. Uçuş ile ilgili gereken ön hazırlıklar tamamlandıktan sonra arazide belirlenen en uygun noktaya sabit Global Positioning System (GPS) aleti kurulmuş ve veriler WGS84 koordinat sisteminde toplanmıștır. İHA verilerini analiz etmek için Pix4D yazılımı kullanılmıştır. Modelleme için yüksek nokta yoğunluğu (high point density) tercih edilmiştir.

Çalışmada kullanılan İHA sistemi sabit olarak kurulan bir adet GNSS alıcısı üzerinde bulunan frekans sağlayıcılar ile çalışmaktadır. Bu frekans sağlayıcılar İHA'ya anlık olarak konum bilgisini vermektedir. İHA sistemi ile uçuş esnasında çekilen fotoğraflara elde edilen anlık konum bilgileri otomatik olarak yazılmaktadır. Anlık konum bilgisi gerçeğe çok yakın olarak elde edilmektedir. Gerçek konumu bulabilmek için verilerin aktarımı yapılırken iki farklı yöntem kullanılmaktadır. İlk olarak sabit olarak kurulan GNSS alıcısının konumu "Real Time Kinematic-RTK" yöntemi ile ölçülür. Bu ölçülen değer sabit GNSS alıcısının konumu olarak kullanılır. Diğer bir yöntem ise "Post Process Kinematic- PPK" yöntemi ile sabit GNSS alıcısının konumu hesaplanır. Bu çalışmada RTK yöntemi ile sabit GNSS alıcısının konumu belirlenmiştir. Uydudan alınan sinyallerin kesintisiz ve sağlıklı bir şekilde alınabilmesi için sistem açık bir alana kurulmuştur. Çalışma alanına ait İHA sisteminden elde edilen 216 fotoğraf üzerinden yapılan değerlendirme sonucunda ilk olarak 460.084 adet bağlama noktası (tie point) kullanılmıştır (Şekil 3). Bağlama noktaları otomatik olarak oluşturulduktan sonra 120367026 adet yoğun nokta bulutu üretilmiştir.

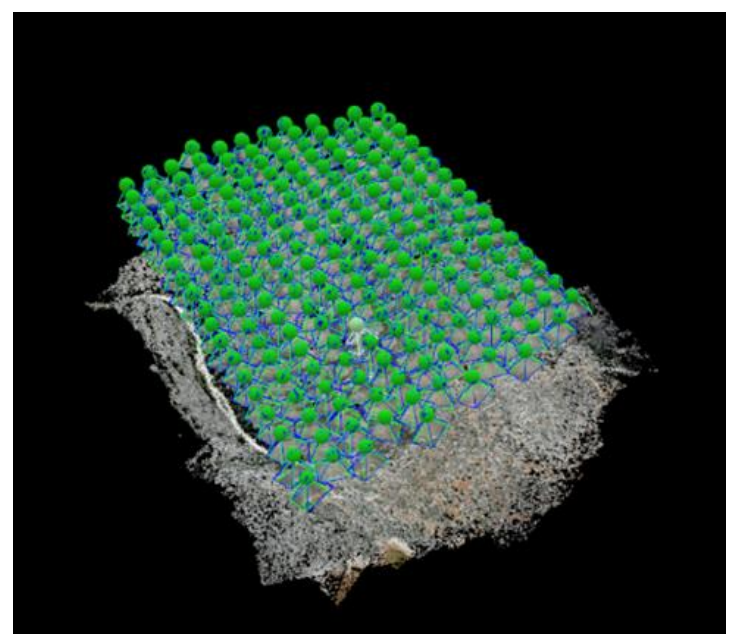

Şekil 3. Kamera pozisyonları ve bağlama noktaları 
Tablo 1. Çalışmada kullanılan İHA sisteminin teknik özellikleri

\begin{tabular}{|l|l|}
\hline Ağırlık (Kamera ile) & Yaklaşık 0,73 kg \\
\hline Kanat Genişliği & $96 \mathrm{~cm}$ \\
\hline Malzeme & $\begin{array}{l}\text { EPP Köpük, Karbon, } \\
\text { Kompozit malz } \\
\text { Elektrikli pervane, 160 W } \\
\text { firçasız DC motor }\end{array}$ \\
\hline GNSS/RTK alıcısı & L1/L2, GPS \& GLONASS \\
\hline Batarya & 11.1 V, 2150 mAh \\
\hline Maksimum uçuş & 40 dakika \\
\hline Belirlenen uçuş hızı & $40-90$ km/s \\
\hline Radyo link mesafesi & 3 km'ye kadar \\
\hline Max rüzgâr & 45 km/s'e kadar \\
\hline İniş doğruluğu & Yaklaşı 5 m hassasiyetle \\
\hline 3B Çizim programı & Menci, Pix4D Mapper \\
\hline
\end{tabular}

SYM oluştururken araziyi tam olarak yansıtmak için filtreleme, gürültü noktaları azaltımı gibi nokta bulutunun ön işlemleri yapılmıștır. Gürültü noktaları CloudCompare 2.9.1 yazılımında bulunan Noise Filter fonksiyonu ile temizlenmiștir. Filtreleme yöntemleri zemin verisinin üretilmesinde kullanılmaktadır. Zemin verisinin elde edilebilmesi için zemin noktalarının fiziksel karakteristiklerinin anlaşılması gerekmektedir. Bu kapsamda elde edilen nokta bulutu CloudCompare 2.9.1 yazılımına aktarılmış ve SOR Filter seçeneği ile filtreleme ișlemi yapılmıştır. Aynı zamanda, Cloth Simulation Filter (CSF) yöntemi kullanılarak zemin noktaları çlkarılmıştır. SOR filtreleme yöntemi araziye en yakın zemin noktalarını verdiği düşünüldügüünden, SYM için bu yöntemden elde edilen zemin noktaları kullanılmıştır. Çalışamda, raster formatında SYM oluşturulurken Inverse Distance Weighting (IDW) ve Üçgenleme (Triangulation) yöntemleri ayrı ayrı kullanılmıştır. Üçgenleme metodu ile SYM üretiminde Delaunay üçgenleme algoritmasını kullanımıştır. IDW enterpolasyon yöntemi örneklem nokta verilerinden enterpolasyonla grid üretmede çoğunlukla tercih edilen bir yöntemdir (Arslanoğlu ve Özçelik, 2005). Bu enterpolasyon yönteminde enterpole edilecek yüzeyde yakındaki noktalar uzaktaki noktalara göre daha fazla ağırlı̆̆a sahip olmaktadır. IDW tam bir ara değer üreticisidir. IDW yakın noktalara, uzak noktalardan daha yüksek ağırlık değeri atayan ve mümkün olan tüm örnek noktalarını dikkate alan bir tahminleme yöntemidir (Arslanoğlu ve Özçelik, 2005). Grid aralığı $100 \mathrm{~cm}$ olarak girilmiştir. Çalışma alanındaki tüm detayları görebilmek için raster verinin çözünürlüğü 5xYÖA olarak seçilmiştir.

\subsubsection{Arazi ve laboratuvar analizleri}

Çalışma alanında Tersiyer yaşlı karstik erime boşluklu akma izli Karaisalı Formasyonuna ait kireçtaşları izlenmekte olup (Alan vd., 2014) kaya düşmeleri bu kireçtaşlarında gerçekleşmektedir. Arazi çalışmaları kapsamında kireçtaşlarına ait süreksizlik özellikleri belirlenmiş, düşmüş blokların yerleri el GPS'i ile ölçülmüş ve boyutları belirlenmiş, olası düșebilir bloklar tespit edilmiș ve geriye dönük analizlerde kullanılacak gözlem ve incelemeler gerçekleştirilmiştir. Bu çalışmalar sırasında Schmidt sertlik çekici deneyi ile kireçtaşlarının geri sıçrama değerleri belirlenmiş yerinde dayanımı kestirilmeye çalışılmıştır. Ayrıca, 3 ayrı lokasyonda hat etüdü yapılmış ve süreksizliklerin durumu değerlendirilmiștir. Kaya düșmelerinin beklendiği yüzeylerin çok dik ve erişimi çok zor olmasından dolayı hat etüdleri sınırlı sayıda yapılabilmiştir. Calıșma alanında hakim iki adet süreksizlik seti izlenmiştir. Toplam 24 adet erişilebilir mesafede arazinin elverdiği lokasyonlardaki düşmüş bloklar belirlenmiştir. Bu bloklardan bazıları Şekil 4'te verilmiștir. Ayrıca moloz birikimi șeklinde birikmiş kaya blokları da yer yer çalışma alanında izlenmiş ve koordinat bilgileri alınmıştır.

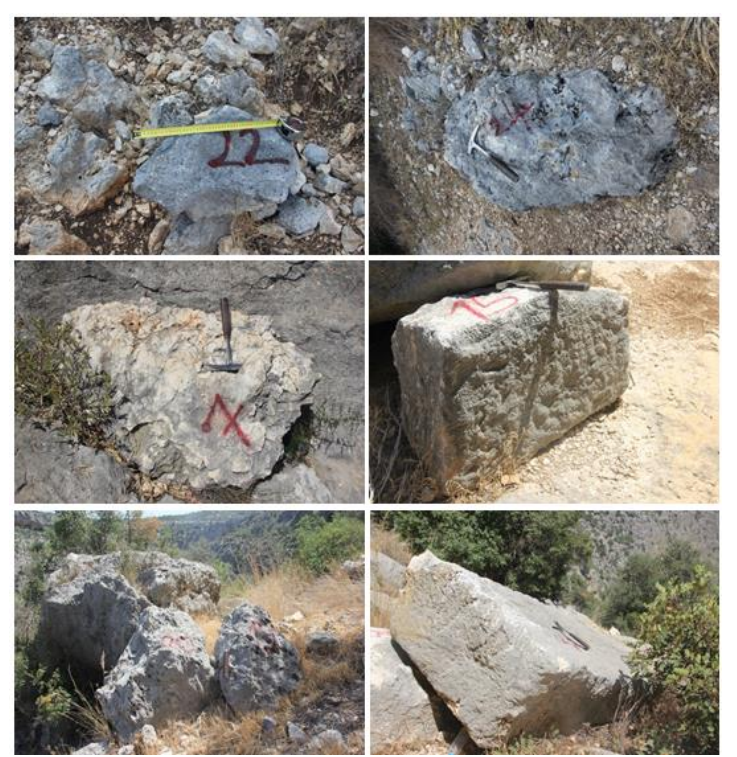

Şekil 4. Calıșma alanında gözlenen düșmüș bloklardan örnekler

Çalışma kapsamında 21 ayrı lokasyonda Schmidt sertlik çekici deneyi yapılmış olup arazide kaya düşme sahası içinde yer alan kayalara ait yerinde tek eksenli sıkışma dayanımı tahmin edilmeye çalıșılmıștır. Buna göre Schmidt sertlik çekici deneyinden elde edilen ortalama tek eksenli sıkıșma dayanımı 60.52 $\pm 22 \quad \mathrm{MPa}$ olarak belirlenmiştir.

Arazi çalıșmaları esnasında süreksizliklere ait eğim ve eğim yönü değerleri belirlenmiş olup; ölçümlerin alındığı koordinatlar hem hat etüdü güzergâhı boyunca hem de kireçtașı yüzeyleri boyunca topoğrafyanın izin verdiği alanlarda yapılmıştır. Şekil 5 süreksizlik ölçümlerinin alındığı noktaları, moloz birikintilerinin yerlerini, kireçtaşı çözünme yapılarını, düșen blokları ve Schmidt ölçüm noktalarının lokasyonlarını göstermektedir. 


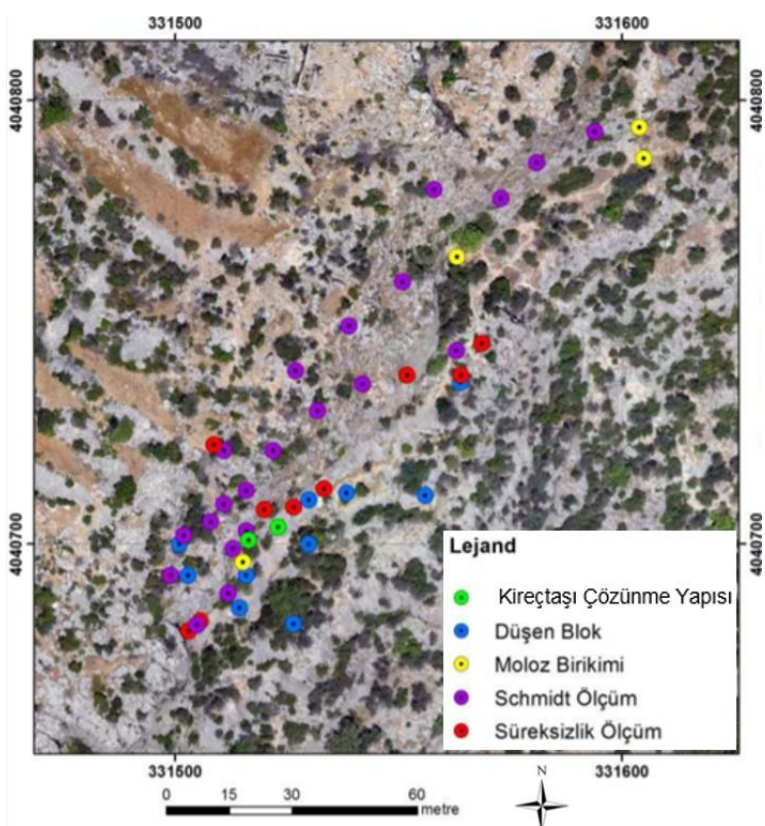

Şekil 5. Arazi çalıșmalarında yapılan değerlendirmelerin lokasyonları

Çalışma alanı dağlık ve engebeli bir topoğrafyaya sahip olup 38 ayrı nokta için süreksizlik ölçümleri yapılmıștır. Toplanan süreksizlik ölçümleri ile kinematik analizler gerçekleştirilmiştir. Kinematik analizlerde de iki ana süreksizlik düzlemi izlenmektedir. Kinematik olarak değerlendirilen süreksizlik verisi arazi gözlemleri ile örtüşmektedir (Şekil 6). Süreksizliklerin dağılımlarını gösteren kontör diyagramı ve yönelimini gösteren gül diyagramı ise Şekil 7'de verilmiștir. Çalışmada kopmuş ve potansiyel düșebilir bloklar da bulunmaktadır. Arazi çalıșmaları sırasında Adam Kayaları figürlerinin üstünde yer alan şevlerde düşmüss, kopmuş blokların yanı sıra potansiyel düzlemsel kayma alanları ile kama tipi süreksizlik olabileceği düşünülen kesimler mevcut olup kinematik açıdan duraysızlıklar da değerlendirilmiștir. Şekil 8'de kinematik olarak düzlemsel kayma, kama türü yenilme ve devrilme türü duraysızlık değerlendirmeleri yer almaktadır.
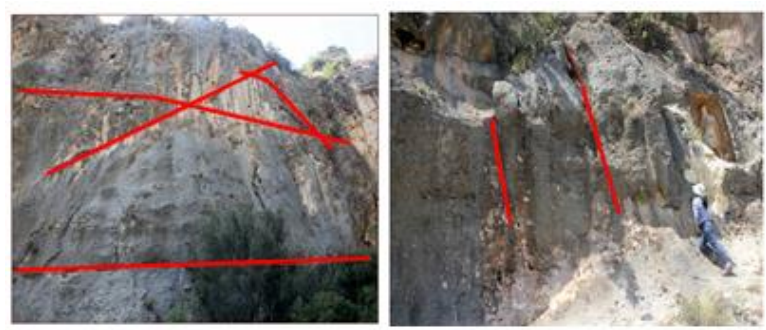

Şekil 6. Çalışma alanında izlenen süreksizlik setlerinden örnekler
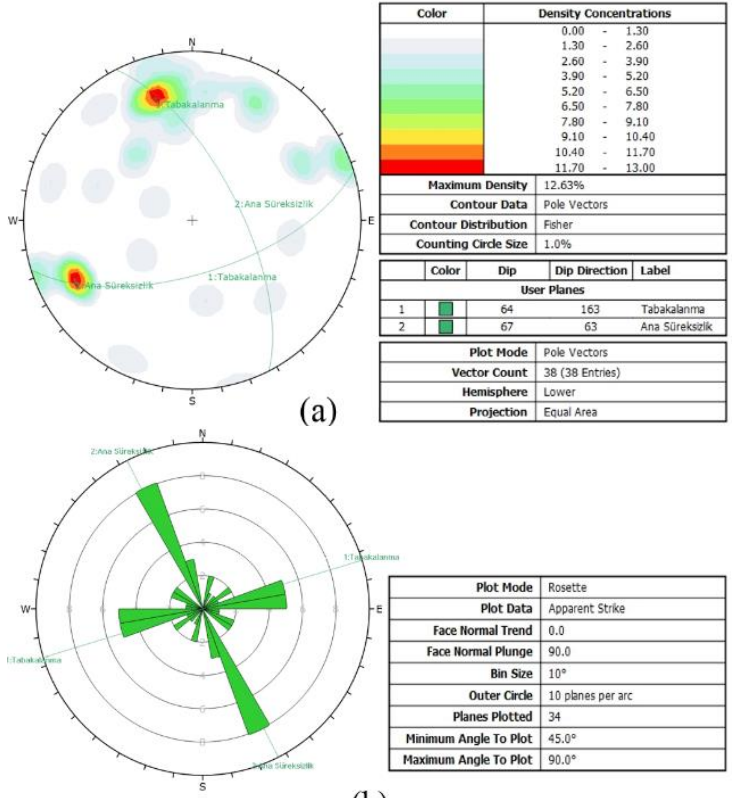

(b)

Şekil 7. Çalışma alanında izlenen ana süreksizlik seti (a) ve süreksizliklere ait gül diyagramı (b).

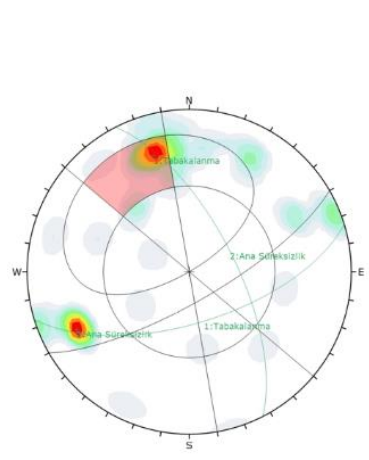

(a)

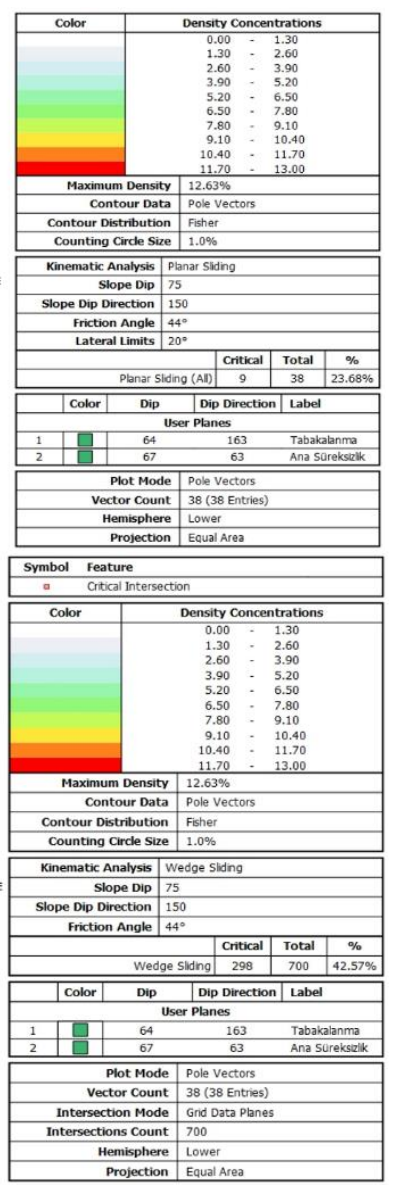




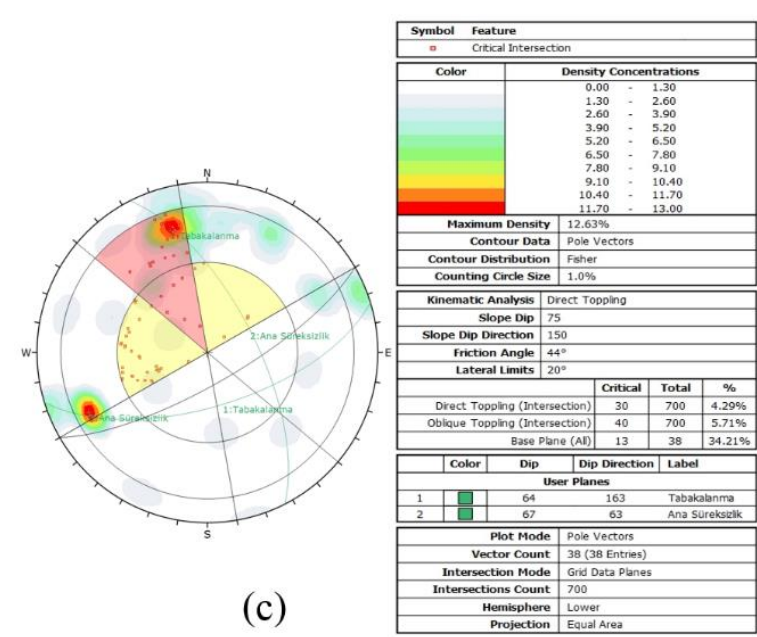

Şekil 8. Kinematik olarak duraysızlıkların değerlendirilmesi, (a) Düzlemsel kayma, (b) Kama tipi yenilme, (c) Devrilme türü yenilme

Çalıșma kapsamında kaya düșmelerinin gerçekleștiği kireçtaşlarının fiziksel (yoğunluk, birim hacim ağırlık, su emme, gözeneklilik), indeks (Brazilian çekilme dayanımı) ve mekanik (tek eksenli sıkışma dayanımı, üç eksenli sıkışma dayanımı, makaslama dayanımı) özelliklerinin belirlenmesine yönelik laboratuvar deneyleri gerçekleştirilmiştir. Çalışma alanının çok dik, engebeli, örnek almanın ve nakletmenin çok güç olduğu bir alanda yer almasından dolayı sınırlı sayıda örnek için değerlendirmeler yapılmıştır. Bu kapsamda araziden blok örnekler alınmıştır. 11 adet silindirik örnek üzerinde gerçekleştirilen değerlendirmelere göre; çalışma alanında yer alan kireçtaşları için yoğunluk değeri ortalama 2.356 $\mathrm{g} / \mathrm{cm}^{3}$, ağırlıkça su emme oranı ortalama $\% 3.52$, gözeneklilik ortalama \%8.4, tek eksenli sıkıșma dayanımı değeri ortalama $56.72 \mathrm{MPa}$, Brazilian Çekilme Dayanımı ortalama $6.67 \mathrm{MPa}$ olarak belirlenmiştir. Yine çalışma kapsamında üç eksenli sıkışma dayanımı deneyi gerçekleştirilmiş olup; bu değerlendirmeler sonucunda makaslama dayanım parametreleri $\mathrm{Cu}=8.91 \mathrm{MPa}$ ve $\phi=44^{\circ}$ olarak belirlenmiștir.

Süreksizlik yüzeylerinin değerlendirilmesi amacı ile kayada makaslama deneyi gerçekleştirilmiştir. $\mathrm{Bu}$ kapsamda sürtünme açlarının tayininde iki yöntem uygulanmıștır. Birinci yöntemde araziden alınan düzensiz kaya bloğu taş testeresi ile kesilmiş bu şekilde hazırlanan iki örnek için yapay süreksizlik yüzeyi oluşturulmuştur. Süreksizlik yüzeyi üzerinde çok aşamalı makaslama deneyi yapılmıștır. Buna göre, toplam sürtünme, temel sürtünme ve pürüzlülük açları sırayla $63^{\circ}, 20^{\circ}$ ve $43^{\circ}$ dir. İkinci yöntemde ise eğdirme (tilt) deneyleri yapılmıştır. Buna göre temel sürtünme açısı $25^{\circ}$, toplam sürtünme açısı $32^{\circ}$ bulunmuştur. Laboratuvardan elde edilen sonuçlar; gerek kireçtaşlarının tanımlanmaları, gerekse modelin kalibre edilmesi ve girdi parametresi olarak kullanılmaları açısından önem taşımaktadır.

\subsection{Kaya Düşme Potansiyelinin Modellenmesi ve Değerlendirilmesi}

Kaya düşmeleri dağlık, kayalık alanlarda en sık karşılaşılan heyelan türüdür. Her ne kadar sınırlı bir hacim içerseler de (Rochet, 1987) yüksek enerji ve hareket kabiliyetinden dolayı en çok zarar veren heyelan türlerindendir (Guzzetti, 2000). Çalışma alanı olarak seçilmiş olan Adam Kayaları için kaya düşmeleri önemli bir doğal tehlikedir. Çalışma alanında iki temel birbirini kesen set yer almaktadır. Bunlardan biri arazinin genel yayllımın, tabakalanmalarını gösteren set, bir diğeri ise onu kesen ana süreksizlik setidir. Ayrıca bu iki ana set dışında ikincil setler de yer almaktadır.

Kaya düşmelerinin modellenmesi aşamasında coğrafi bilgi sistemlerini (GIS) kullanan üç boyutlu nümerik kaya düşmesi analiz programı olan HYSTONE (Agliardi vd., 2009) kullanılmıştır. HY-STONE Guzzetti vd. (2002) tarafından geliștirilen STONE yazılımının son şeklidir. Çalışmada, yerel ve fotogrametrik verilerin girdi olarak kullanıldığı HYSTONE (Agliardi vd., 2009) yazılımı ile kaya düşmelerinin simülasyonu gerçekleştirilmiş ve düşme potansiyeline sahip blokların yayılma ve ilerleme mesafeleri tespit edilmiștir.

$\mathrm{Bu}$ çalışma kapsamında gerçekleştirilen üç boyutlu nümerik kaya düşme analizleri; kaya düşmesi kaynak alanından başlayan kaya bloğunun düşme, sıçrama, yuvarlanma vb. hareketlerini, kaya bloğun duruncaya kadar izlediği yolu, enerji değişimlerini ve hızını içermektedir.

$\mathrm{Bu}$ amaçla SYM, jeomorfoloji ve arazi kullanım haritalarının birleștirilmesinden elde edilen unique condition haritası, kaya düşmesi kaynak alanı, enerji sönümlenmelerini ifade eden normal ve tanjansiyel katsaylar (normal and tangential restitution of coefficient), yüzey sürtünme katsayısı (friction coefficient) ve ilksel durumları ve kontrol parametrelerini içeren form girdi olarak kullanılmaktadır.

\section{BULGULAR}

Kaya düşme analizinde gerekli tüm değerlendirmeler İHA'dan elde edilen SYM verisi ile gerçekleștirilmiştir. IHA sisteminden elde edilen veriler üzerinde yoğun nokta bulutu oluşturulmuş ve 12509 x 13920 boyutunda ve 7 cm çözünürlüğe sahip çalışma alanına ait SYM elde edilmiştir (Şekil 9). SYM oluşturulurken metrekare alan başına ortalama 72 nokta kullanılmış ve alana ait 18171 x 21415 piksel boyutunda ortofoto oluşturulmuştur (Şekil 10). 
SAYISAL YÜKSEKLİK MODELİ (SYM)

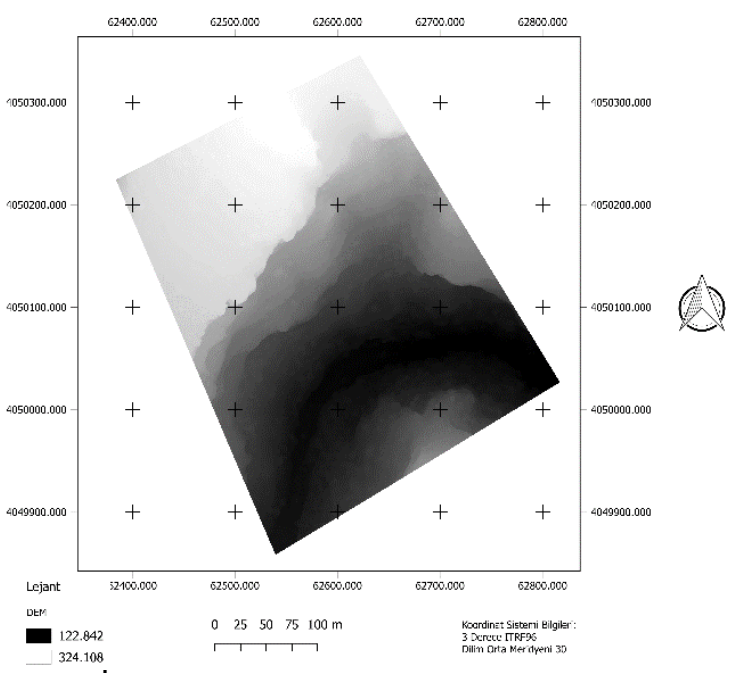

Şekil 9. İHA sisteminden elde edilen SYM

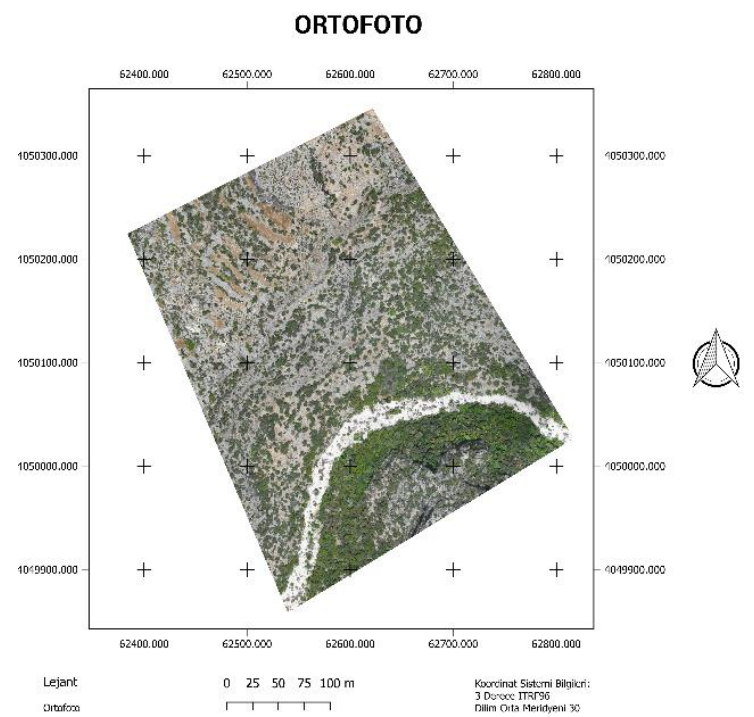

Şekil 10. İHA sisteminden elde edilen Ortofoto

Arazi gözlemleri ve İHA sisteminden elde edilen tüm veriler birlikte değerlendirilerek CBS ortamında kaya düşmesi kaynak alanı oluşturulmuştur. Yine bu alan olușturulurken SYM'den elde edilen eğim haritasından da faydalanılmıștır. Modelleme aşamasında 23 ayrı alanda poligonlar olușturularak kaya düşmesi kaynak alanları hazırlanmıştır. Her kaynak alan içindeki her bir pikselden 20 adet blok fırlatılmıs ve buna göre toplam 29097 adet blok çalışma kapsamında değerlendirilmiștir. SYM ve eğim haritaları kullanılarak kaya düşmesi kaynak alanları belirlenmiștir (Şekil 11).

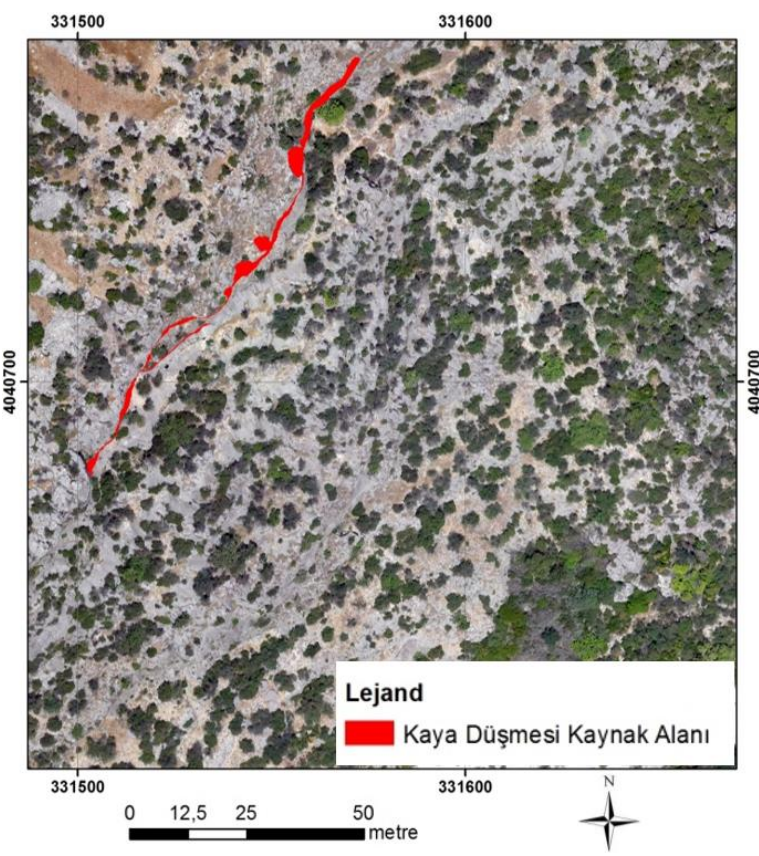

Şekil 11. Kaya düşmesi kaynak alanı

Çalıșma kapsamında olușturulan ortofoto, arazi gözlemleri ve Google Earth görüntülerinden faydalanılarak kaya bloklarının ilerleyeceği yüzeyi tanımlamak için jeomorfoloji ve arazi kullanım haritaları ArcGIS 10.5 yazılımı ile oluşturulmuştur. Daha sonra bu iki harita birleştirilerek her iki haritaya ait arazi sınıfinı temsil eden ve o parametreleri içinde barındıran "unique condition" haritası elde edilmiștir (Şekil 12).

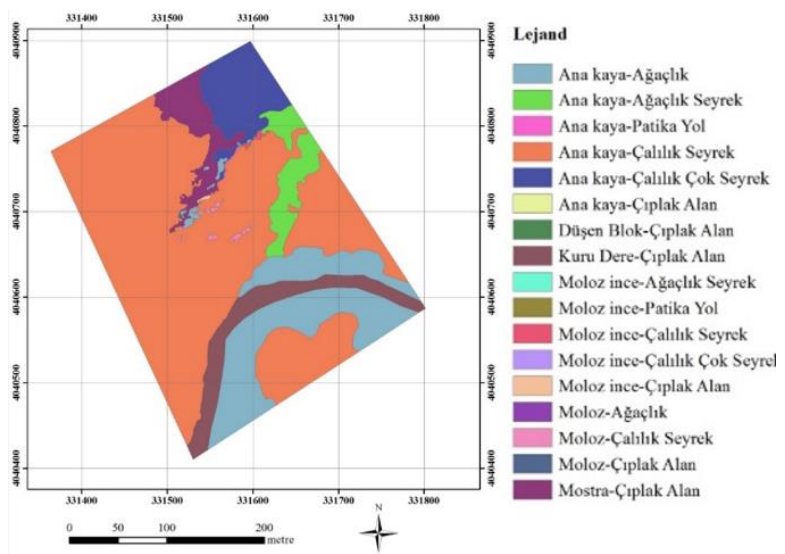

Şekil 12. "Unique condition" haritası

Modelleme çalıșmalarında en önemli hususlardan biri ortamı en iyi temsil edecek sistemin kurulmasıdır. Çalışmanın bu aşaması, araziyi temsil edecek yüzey sinıflarına ait "unique condition" haritasından faydalanılarak bloğun hareketi sirasinda gerek normal ve tanjansiyel ve gerekse sürtünme değerlerinin seçilmesi kısmını oluşturmaktadır. Böylece, düșen bloğun topoğrafyaya temas ettiği noktalardaki enerji sönümlenmelerini kontrol eden normal ve tanjansiyel katsayıları (normal (En) and tangential (Et) restitution coefficient) ve düșen blok ile yüzey arasındaki sürtünme katsayısı (friction coefficient 
(At)) belirlenmektedir. Bu katsayllar, düşen bloğun ve yüzeyin özelliklerine göre değişim göstermektedir. Literatürde bu katsayları kontrol eden farklı yüzey tanımları önerilmektedir. $\mathrm{Bu}$ tanımlar; çalışma alanında bulunan jeolojik birimlere ve arazi kullanımına göre değişiklik göstermektedir. $\mathrm{Bu}$ amaçla bu parametreleri belirlemek ve modeli kalibre etmek için uygulanan yöntemlerden biri arazide kaya yuvarlama deneyi olup, çalışma alanın çok dik, erişilmesi çok güç yapıda olması ve ayrıca ağaçlık, çalılık alanlar içermesinden dolayı yapılamamıştır. $\mathrm{Bu}$ deneyin yerine gerekli parametrelerin belirlenmesi için geriye dönük analizlerden, arazi çalışmaları sırasında alınan örnekler üzerinde gerçekleştirilen deneylerden ve literatürden faydalanılmıștır.

Çalışma kapsamında gerçekleştirilen geriye dönük analizler düşen blokların lokasyonlarının ve düşmüş blokların biriktiği alanların belirlenmesi, modelin izleyeceği yolun ve ilerleme mesafelerinin kestirilmesi anlamında önem taşımıştır. Arazi çalışmaları sırasında düşmüş bloklar, kaya birikim alanları ve moloz birikim alanları belirlenmiş model aşamasında değerlendirilmiştir. Bu parametrelerin belirlenmesi için çalışılan sayısal arazi modelinin çözünürlüğüne eşit ya da en yakın çözünürlükte çalışmalar dikkate alınmış ve "unique condition" haritasında yer alan yüzey özelliklerine göre sönümlenme katsayıları ve sürtünme açları belirlenmiştir.

Laboratuvar çalışmaları ile malzemeye ait temel sürtünme açısı, süreksizliklere ait süreksizlik açıları belirlenmiş ve geriye dönük analizlerle birlikte değerlendirilerek çalışma alanını temsil edecek sönümlenme katsayıları ve sürtünme açıları oluşturulmuştur. Böylece HY-STONE yazılımında çok sayıda model geliştirilerek çalışma alanını en iyi yansitan parametrelerle analizler gerçekleştirilmiştir. Modelleme aşamasında kullanılan normal (En), tanjansiyel (Et) katsayıları ile yüzey sürtünme açısı (At) Tablo 2'de verilmiştir.

Tablo 2. "Unique condition" haritasinda yer alan birimler ve normal (En), tanjansiyel (Et) katsayıları ile yüzey sürtünme açıları (At).

\begin{tabular}{lccc}
\hline Arazi Sınıfı & At & En & Et \\
\hline Ana kaya-Ağaçlık & 0,5 & 35 & 55 \\
\hline Mostra-Çıplak Alan & 0,43 & 50 & 65 \\
\hline Moloz-Çıplak Alan & 0,45 & 38 & 60 \\
\hline Düşen Blok-Çıplak Alan & 0,45 & 47 & 63 \\
\hline Moloz ince-Çıplak Alan & 0,48 & 30 & 53 \\
\hline Moloz-Çalıık Seyrek & 0,5 & 25 & 50 \\
\hline Moloz-Ağaçlık & 0,52 & 23 & 48 \\
\hline Kuru Dere-Çıplak Alan & 0,45 & 35 & 55 \\
\hline Ana kaya-Çalılık Seyrek & 0,48 & 37 & 57 \\
\hline Moloz ince-Patika Yol & 0,47 & 28 & 50 \\
\hline Moloz ince-Çalıık Çok Seyrek & 0,51 & 25 & 52 \\
\hline Moloz ince-Ağaçlık Seyrek & 0,53 & 23 & 50 \\
\hline Moloz ince-Çalıık Seyrek & 0,52 & 25 & 51 \\
\hline Ana kaya-Patika Yol & 0,49 & 32 & 57 \\
\hline Ana kaya-Çalılık Çok Seyrek & 0,49 & 37 & 58 \\
\hline Ana kaya-Ağaçlık Seyrek & 0,46 & 37 & 56 \\
\hline Ana kaya-Çıplak Alan & 0,45 & 45 & 60 \\
\hline
\end{tabular}

Kontrol formu modelin çalışması için gereken girdi parametreleri ile o kaya düşmesi alanını kontrol eden malzemenin yoğunluğu, blok boyutu, şekli gibi parametreleri ve çıtı verilerini içermektedir. Bu form içinde yer alan parametreler değiştirilerek farklı modellemeler yapılmaktadır. Sönümlenme katsayıları ile yüzey sürtünme açıları için farklı değerler kullanılarak çok sayıda farklı model elde edilmiș, ilerleme mesafesi her bir model için değerlendirilmiştir. Böylece çalışma alanını en iyi temsil eden model belirlenmiştir. Kaya düşmelerinde blokların şekli için arazi gözlemleri etkili olmuştur. HY-STONE yazılımında küre, silindir ve disk şeklinde örnekler için analizler gerçekleștirilmekte olup, araziyi en iyi temsil ettiği düşünülerek blok şekli küre olarak seçilmiştir. Blokların çapı olarak arazide düşmüş bloklara ait ölçümler alınmıș hacimleri hesaplanmıș bu arada bu hacme eşit kürenin çapı belirlenmiștir. Buna göre ortalama çap olarak $0.8 \mathrm{~m}$ alınmıştır. Malzemenin yoğunluğu araziden alınan kireçtaşı örnekleri için gerçekleștirilen yoğunluk değerlerinden alınmıştır. Buna göre ortalama yoğunluk değeri olarak 2. 356 $\mathrm{kg} / \mathrm{m}^{3}$ kullanılmıștır. Çalışma kapsamında HYSTONE yazılımı çok sayıda model için çalıştırılmış, gerek araziden elde edilen veriler, gerek laboratuvar çalışmaları ve gerekse literatürden faydalanılarak oluşturulmuş girdi parametreleri kullanılmıştır.

Çalışma kapsamında değerlendirilen modellerden araziyi en iyi temsil ettiği düşünülen modele ait çıtılır verilmektedir. Buna göre HYSTONE yazılımı kullanılarak gerçekleştirilen üç boyutlu nümerik kaya düşmesi analizleri sonucunda blokların izleyeceği yol ile her bir piksele düşen blok sayısı da (Şekil 13) yer almaktadır. İHA ile uçulan, şevlerin üstünden analiz edilen kaya düşmeleri için gerçekleștirilen analizler sonucunda özellikle Adam Kayaları'nın olduğu kısımlarda kayaların büyük bir kısmının enerjilerinin sönümlendiği, kaya blokların bu alanda biriktiği izlenmektedir. Bu alanların kaya düşmesi riski altında olduğu blok ilerleme haritasında görülmektedir.

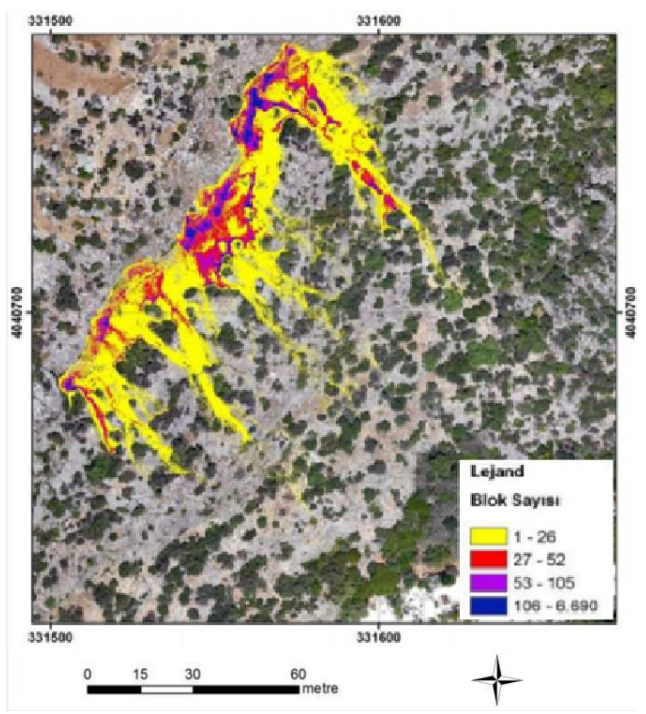

Şekil 13. Kaya blokların ilerleme mesafesi ve sayısı 
Çalışma kapsamında düş̧ebilecek blokların toplam (rotasyonel+ilerleme), ortalama kinetik enerji (joule) durumunu gösteren harita Șekil 14'te yer almaktadır. Arazi gözlemlerinde düşen blokların Adam Kayaları'nın önündeki patika yolu aşarak yamaç aşağı belli bir miktar daha ilerlediği gözlenmiş olup arazi çalışmaları çalışılan modeli doğrulamaktadır. Çalışma kapsamında toplam ortalama kinetik enerji değeri 69.297 kjoule olarak belirlenmiştir. Bu değer, düşen blokların oldukça yüksek enerjiye sahip olduğunu göstermekte olup, kaya düşmelerinden korunmaya yönelik gerçekleștirilecek önlemlerin alınmasında önem taşımaktadır. İlk düştüklerinde oldukça yüksek potansiyel enerjiye sahip bloklar Adam Kayaları önündeki çıplak kayalık alana çarpmakta ve büyük oranda sönümlenmektedir. Böylece özellikle patika yolun bulunduğu bu kesimlerde kaya düşmelerine bağlı zararlar oluşabilecektir. Çalışma kapsamında modellenen düşebilecek bloklara ait ortalama hız $(\mathrm{m} / \mathrm{s})$ değerlerini gösterir harita Şekil 15'te verilmiştir. Buna göre çalışma alanı için belirlenmiş ortalama hız değeri $41.50 \mathrm{~m} / \mathrm{s}^{\prime}$ dir.

Bloklara ait sıçrama yüksekliklerine bakıldığında $70,09 \mathrm{~m}$ ye ulaşan değerler yer almaktadır (Şekil 16). Bu yüksek değerler özellikle şevin en dik olduğu, ilk kaya düşme alanından serbest düştüğü kısımlarda izlenmektedir.

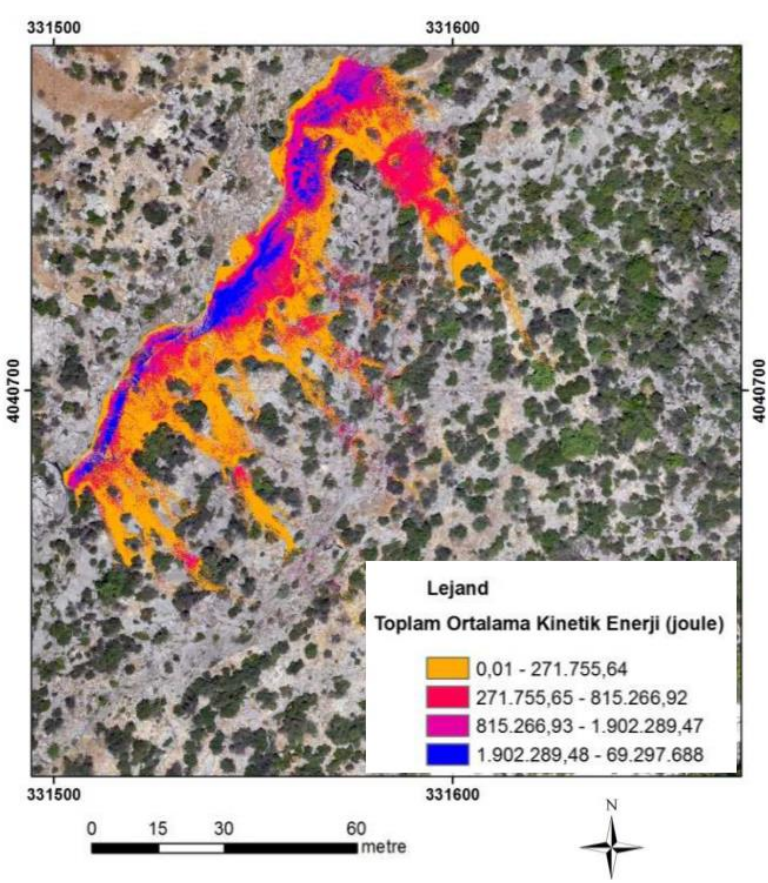

Şekil 14. Kaya düşmelerine ait toplam ortalama kinetik enerji (joule).

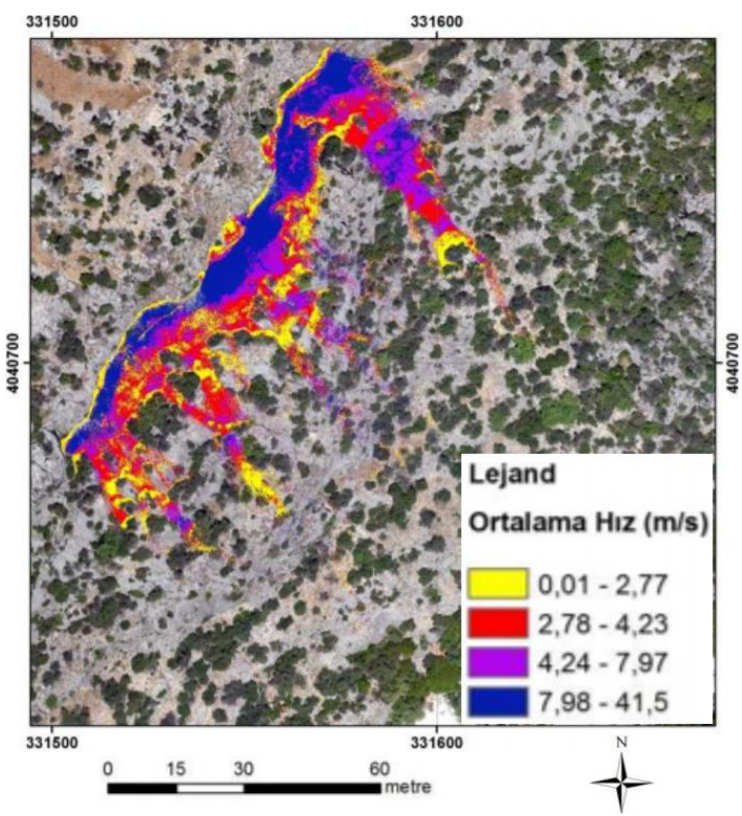

Şekil 15. Kaya düşmelerine ait ortalama hız

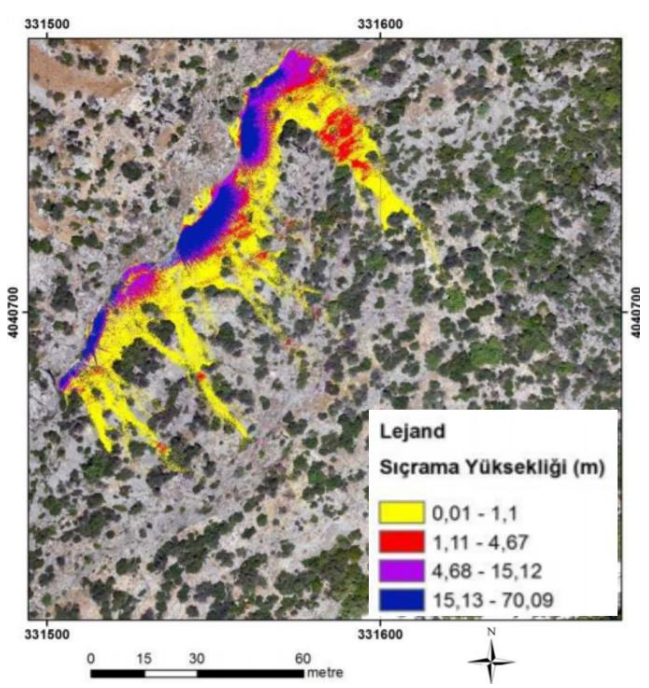

Şekil 16. Kaya düşmelerine ait sıçrama yükseklikleri

\section{SONUÇLAR}

Adam Kayaları ve yakın çevresindeki kaya düşmelerinin değerlendirilebilmesi için İHA sisteminden elde edilen veriler ile birlikte ortofotolar, yerinde ve laboratuvar deneylerinden elde edilen sonuçlar kullanılarak çalışma alanının topografyasını yansıtan veriler elde edilmiş ve analizler gerçekleştirilmiştir. Genel olarak, bu çalışma IHA sistemlerinin bu tür çalışmalarda kullanılabilirliğini ortaya koymaktadır.

Ancak İHA sisteminin bu tür topografyalarda kullanımında dikkat edilmesi gereken hususlar bulunmaktadır. IHHA sisteminden elde edilen verilerin analizi için sisteme uygun üretilen yazılım ile araziye ait topografik veriler gerekli parametreler girildikten sonra otomatik olarak üretilmektedir. Bu çalışmada, Pix4D Mapper 3.2.23 yazılımının elde edilen verilerin filtrelenmesinde birkaç noktada yetersiz kaldığı görülmüştür. Genel olarak tepede ve yüzeyde bulunan çalı, ağaç ve ağaççıkları program 
tamamen filitreyebilmiş ancak kayalıkların iç kısmına doğru fazla eğimin olduğu yan yüzeylerdeki çalılıkları tam olarak filtreleyememiștir. SYM'de oluşan üçgenler detaylı olarak incelenmiștir. İnceleme sonucunda bazı noktalarda üçgenlerin yanlış bağlandığı kanısına varılmıştır. Her ne kadar üçgenler üzerinde editleme yapılsa da tam olarak araziyi birebir yansıtamadığı görülmüştür. Aslında bu durum İHA sisteminden elde edilen tüm topografik veriler için geçerlidir. Çünkü kaya blokları arazi yüzeyinde girinti çıkıntı oluşturduğu için editleme işlemi sırasında üçgenlere arazi şekli tam olarak verilememektedir. Bu durum bizim çalışma alanında oldukça minimum seviyededir ama benzeri yapılacak çalışmalarda bu hususa dikkat edilmesi gerekmektedir. Çalışmada bu durum göz önününe alınmış ve çok sayıda kaya düşme simülasyonu gerçekleștirilmiștir. Elde edilen modeller arasından gerçeği yansıtan en uygun modeller seçilmiştir. Arazi gözlemlerinde düşen blokların Adam Kayaları'nın önündeki patika yolu aşarak yamaç aşağı belli bir miktar daha ilerlediği gözlenmiş olup arazi çalışmaları çalışılan modeli doğrulamaktadır.

Genel olarak SYM 1/25000 ölçekli topografik haritalardan üretilmektedir. $\mathrm{Bu}$ ölçekteki bir haritadan elde edilen SYM'de $1 \mathrm{~cm} 250$ m'ye karșllık geleceği için topografyaya ait gerçek detayları yansitamayacak ve hassas bir modelleme gerçekleştirilemeyecektir. İHA sisteminden elde edilen bu veriler $7 \mathrm{~cm}$ çözünürlüğe sahip olup araziye ait en ufak detayları bile yansitabilmektedir.

$\mathrm{Bu}$ çalışma İHA sisteminin bu tür topografyalardaki kayalık alanlardaki ilk kullanımıdır. Çalışma kapsamında HY-STONE yazılımı çok sayıda model için çalıştırılmış, gerek araziden elde edilen veriler, gerek laboratuvar çalışmaları ve gerekse literatürden faydalanılarak oluşturulmuş girdi parametreleri kullanılmıştır. Buna göre çalışma alanını en iyi temsil ettiği düşünülen model çalışma kapsamında model çıktısı olarak sunulmuştur. Çok sayıda model üzerinde yapılan değerlendirmeler sonucunda sunulan haritaların ortamı en temsil eden model olduğu belirlenmiştir.

Çalışma kapsamında toplam ortalama kinetik enerji değeri 69297 kjoule olarak belirlenmiștir. Bu değer, düşen blokların oldukça yüksek enerjiye sahip olduğunu göstermekte olup, kaya düşmelerinden korunmaya yönelik gerçekleștirilecek önlemlerin alınmasında önem tașımaktadır. İlk düștüklerinde oldukça yüksek potansiyel enerjiye sahip bloklar Adam Kayaları önündeki çıplak kayalık alana çarpmakta ve büyük oranda sönümlenmektedir. Böylece özellikle patika yolun bulunduğu bu kesimlerde kaya düşmelerine bağlı zararlar oluşabilecektir. Buna göre çalışma alanı için belirlenmiş ortalama hız değeri $41.50 \mathrm{~m} / \mathrm{s}^{\prime}$ dir. Bloklara ait sıçrama yüksekliklerine bakıldığında $70,09 \mathrm{~m}$ ye ulaşan değerler yer almaktadır. $\mathrm{Bu}$ yüksek değerler özellikle şevin en dik olduğu, ilk kaya düşme alanından serbest düştüğü kısımlarda izlenmektedir.
Yapılan değerlendirmelerde kaya düşmelerinin hareketi esnasındaki durumu (yuvarlanma, sıçrama), yayılma ve ilerleme mesafeleri, hızları ve kinetik enerjileri belirlenmiștir. Böylece risk altındaki elemanlar değerlendirilmektedir. Buna göre çalışma alanında risk altındaki eleman sınıfını patika yol, Adam Kayaları ziyarete gelecek turistler ve bu alandan geçecek olan her türlü canlı olușturmaktadır.

Çalışmada,

kaya

düşmelerinin değerlendirilmesine yönelik ülkemizde daha önce hiç uygulanmayan IHA sistemi kullanılarak elde edilen topografik veriler (SYM, eğim) kullanılmıștır. Bu veriler üzerinde üç boyutlu modellemelerle olası blokların kestirilmesi, bu blokların ilerleme mesafelerinin belirlenmesi, sahip oldukları hızların,enerjilerin ve sıçrama yüksekliklerinin değerlendirilmesi ile bu çalışma bir farkındalık yaratmaktadır. Bu çalışmanın sonuçları literatüre ve ileride yapılacak olan benzeri çalışmalara büyük katkı sağlayacak ve altlık olacak niteliktedir.

\section{BILGILENDIRME/TEŞEKKÜR}

115 Y846 nolu projeye vermiş oldukları destekten dolayı TÜBiTAK'a teşekkürlerimizi sunarız. Laboratuvar çalışmalarında vermiş oldukları değerli katkılarından dolayı Ankara Üniversitesi Jeoloji Mühendisliği Bölümü öğretim üyesi Sayın Prof. Dr. Kamil Kayabalı'na ve ekibine teșekkür ederiz. Kaya düşme analizlerinin gerçekleștirildiği yazılımın kullanılmasında desteklerini esirgemeyen Prof. Dr. Giovanni Battista Crosta'ya, Doç.Dr. Paolo Frattini'ye ve Doç.Dr. Federico Agliardi'ye teşekkürlerimizi sunarız. Son olarak, İzmir Kâtip Çelebi Üniversitesi'ne desteklerinden dolayı teşekkür ediyoruz

\section{KAYNAKÇA}

Agliardi, F., Crosta, G. B., P. Frattini, P. (2009). Integrating rockfall risk assessment and countermeasure design by 3D modelling techniques. Natural Hazards Earth Syst. Sci., 9, 1059-1073.

Alan, İ., Balcı, V., Elibol, H. (2014). 1/100000 ölçekli Türkiye Jeoloji Haritaları Silifke, Paftaları,MTA, Ankara, 31-32.

Arslanoğlu, M., Özçelik, M. (2005). Sayısal Yükseklik verilerinin iyileștirilmesi. TMMOB Harita ve Kadastro 10. Teknik Kurultayı, 28 Mart-1 Nisan, Ankara.

Bonneau, D.A., Hutchinson D.J. (2019). The Use Of Terrestrial Laser Scanning for the Characterization of A Cliff-Talus System in the 
Thompson River Valley, British Columbia, Canada, Geomorphology 327, 598-609.

Deliormanl, A.H., Maerz, N.H., Otoo, J. (2014). Using Terrestrial 3D Laser Scanning And Optical Methods to Determine Orientations of Discontinuities At A Granite Quarry, International Journal of Rock Mechanics \& Mining Sciences, 66, 41-48.

Esposito S., Fallavollita P., Wahbeh W., Nardinocchi C., and Balsi M. (2014). Performance Evaluation Of UAV Photogrammetric 3D Reconstruction". IGARSS, 12-25.

Gonçalves, J.A., Henriques, R. (2015). UAV Photogrammetry for Topographic Monitoring of Coastal Areas, ISPRS Journal of Photogrammetry and Remote Sensing, 104, 101-111.

Google Earth, (2018). https://www.google.com.tr/intl/tr/earth/

Guisado-Pintado, E., Jackson, Derek W.T.J., Rogers, D. (2019). 3D Mapping Efficacy Of A Drone And Terrestrial Laser Scanner Over A Temperate Beach-Dune Zone, Geomorphology, 328, 157172.

Guzzetti, F. (2000). Landslide fatalities and the evaluation of landslide risk in Italy, Engineering Geology, 58, 89-107.

Guzzetti, F., Crosta, G., Detti, R., Agliardi, F. (2002). "STONE: A Computer Program For The Threedimensional Simulation of Rock-Falls, Computers \& Geosciences, 28, 1079-1093.

Kasprak, A., Bransky, N.D., Sankey, J.B., Caster, J., Sankey, T.T., (2019). The effects of topographic surveying technique and data resolution on the detection and interpretation of geomorphic change, Geomorphology, 333, 1-15.

Kromer, R.A., Hutchinson, D.J., Lato, M.J., Gauthier, D., Edwards, T. (2015). Identifying rock slope failure precursors using LiDAR for transportation corridor hazard management, Engineering Geology, 195, 93-103.

Lai, P., Samson, C., Bose, P. (2014). Visual enhancement of 3D images of rock faces for fracture mapping, International Journal of Rock Mechanics \& Mining Sciences, 72, 325-335.

Lan, H., Martin, C.D., Zhou, C., Lim, C.H. (2010). Rockfall hazard analysis using LiDAR and spatial modeling, Geomorphology 118, 213223.
Lato, M.J., Vöge, M. (2012). Automated mapping of rock discontinuities in 3D lidar and photogrammetry models, International Journal of Rock Mechanics \& Mining Sciences, 54,150158.

Salvini, R., Francioni, M., Riccucci, S., Bonciani, F., Callegari, I. (2013). Photogrammetry And Laser Scanning for Analyzing Slope Stability And Rock Fall Runout Along The Domodossola-Iselle Railway, The Italian Alps, Geomorphology, 185, 110-122.

Solazzo, D., Sankey J.B., Sankey T.T., Seth M.M., (2018), Mapping and Measuring Aeolian Sand Dunes With Photogrammetry And Lidar From Unmanned Aerial Vehicles (UAV) and Multispectral Satellite Imagery on the Paria Plateau, AZ, USA, Geomorphology, 319, 174185.

Şanlıglu, I., Zeybek, M., Karauguz, G. (2013). Photogrammetric Survey and 3D Modeling of Ivrız Rock Relief in Late Hittite Era. Mediterranean Archaeology and Archaeometry, $13,147-157$.

Thoeni, K., Giacomini, A., Lambert, C., Sloan, S.W., Carter, J.P. (2014). A 3D Discrete Element Modelling Approach for Rockfall Analysis with Drapery Systems, International Journal of Rock Mechanics \& Mining Sciences, 68, 107-119.

Uysal, M., Uslu, A. (2017). Arkeolojik Eserlerin Fotogrametri Yöntemi İle 3B Modellenmesi: Demeter Heykeli Örneği. TUFUAB IX. Teknik Sempozyumu.

Vasuki, Y., Holden, E., Kovesi, P., Micklethwaite, S. (2014). Semi-Automatic Mapping of Geological Structures Using UAV-Based Photogrammetric Data: An Image Analysis Approach, Computers \& Geosciences, 69, 22-32.

Yakar, M., Yılmaz, H.M., Ylldız, F., Zeybek, M., Sentürk, H., Çelik, H. (2009). Silifke-Mersin Bölgesinde Roma Dönemi Eserlerinin 3B Modelleme Çalışması ve Animasyonu. TMMOB Harita ve Kadastro Mühendisleri Odası 12. Türkiye Harita ve Teknik Kurultayı, 11-15 Mayıs, Ankara.

Walton, G., Diederichs, M.S., Weinhardt K., Delaloye D., Matthew J.L., Punkkinen A. (2018). Change detection in drill and blast tunnels from point cloud data, International Journal of Rock Mechanics and Mining Sciences, 105, 172-181.

Wenzhong, S., Deng S., Wenbing, X., (2018). Extraction of Multi-Scale Landslide Morphological Features Based on Local Gi* Using Airborne Lidar-Derived DEM, Geomorphology 303, 229-242. 
URL-1: https://www.google.com/search?q=adam+

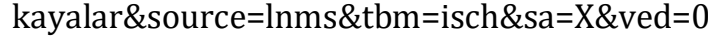
ahUKEwjhneyw2MDjAhW3QkEAHc0QBYEQ_A UIESgB\&biw $=1229 \&$ bih $=610$. 